\title{
Jaminan Perlindungan Hak Pilih dan Kewajiban Negara Melindungi Hak Pilih Warga Negara dalam Konstitusi (Kajian Kritis Pemilu Serentak 2019)
}

\author{
Felani Ahmad Cerdas ${ }^{1}$ \\ Hernadi Afandi ${ }^{2}$ \\ ${ }^{1}$ Program Magister Ilmu Hukum Pascasarjana Universitas Padjajaran, Bandung, Indonesia \\ E-mail:felaniahmad@gmail.com \\ ${ }^{2}$ Fakultas Hukum Universitas Padjajaran, Bandung, Indonesia \\ E-mail: Hernadi.affandi@unpad.ac.id
}

\begin{abstract}
Human rights are a fundamental right that has been carried out by a human being while guarantees in the state in protection and regulation must be guaranteed in a fundamental law, namely the constitution of a country in Indonesia itself in the protection of human rights in Article 1 article (2) Article 28 Article 2 Paragraph (1) Article 6 A (1) Article 9 Paragraph (1) Article 22 (c) In essence the protection of the right to vote and be elected by the state is absolutely done while the implementation is stated in Law No. 39 of 1999 concerning Human Rights In article 23 which reads: everyone is free to choose and and has political beliefs, that means the protection of voting rights and voting has been carried out in the Indonesian state's legal politics in practice the suffrage is implemented by the General Election Commission in implementing the right to vote and be elected this is very difficult because the population system in Indonesia is still inadequate as a result of the right to vote this is not obtained by the citizens themselves.
\end{abstract}

Keywords: Human Rights; Protection of suffrage; Constitution

\section{A. PENDAHULUAN}

Perkembangan pemikiran HAM di Indonesia mengalami pasang dan surut yang secara jelas dapat terlihat melalui tabel periodesasi sejarah Indonesia, mulai tahun 1908 hingga sekarang. Pada dasarnya, konsep HAM bukanlah sematamata sebagai konsep tentang hak-hak asasi individual Konsep pemikiran HAM telah dikenal oleh Bangsa Indonesia terutama sejak tahun 1908 lahirnya Budi Utomo, yakni di tahun mulai timbulnya kesadaran akan pentingnya pembentukan suatu negara bangsa (nation state) melalui berbagai tulisan dalam suatu Majalah Goeroe Desa. Konsep HAM yang mengemuka adalah konsep-konsep mengenai hak atas kemerdekaan, dalam arti hak sebagai bangsa merdeka yang 
bebas menentukan nasib sendiri (the rights of self determination). ${ }^{1}$ Jhon locke di sebut sebagai bapak hak asasi manusia menurut teori perjanjuan jhon locke menjadi dasar negara dengan kekuatan terbatas menurut locke membentuk satu kesatuan masyarakat atau negara, rakyat tetap memiliki hak alamiah (Natural rights) sebagai inalienable rights. Negara atau pemerintah tidak boleh Mengangu atau merampas hak hak alamiah

Pasal 1 ayat 3 UUD NRI 1945 menyatakan bahwa Indonesia adalah negara hukum konsekuensi dari negara hukum adalah menepatkan hukum sebagai panglima di dalam penyelenggaran negara Indonesia Menurut J.G. Steenbeek, konstitusi sebagai aturan dasar tertinggi dalam suatu negara minimal memuat tiga hal pokok yaitu: (1) adanya jaminan dan penghormatan terhadap Hak asasi manusia dan warga negaranya; (2) ditetapkannya susunan kenegaraan suatu negara yang bersifat fundamental; dan (3) adanya pembagian dan pembatasan tugas ketatanegaraan yang juga bersifat fundamental ${ }^{2}$

Setiap negara wajib melindungi dan menegakan hak asasi manusia Pengaturan HAM di dalam konstitusi menunjukkan bahwa HAM sudah menjadi materi muatan konstitusi, sehingga mengikat semua pihak terkait terutama penyelenggara negara dan pemerintahan baik di tingkat pusat maupun daerah, baik eksekutif, legislatif, maupun yudikatif.

Pemenuhan HAM bukan hanya tanggung jawab penyelenggara negara dan pemerintahan tersebut, tetapi juga semua orang dan warga negara. Namun demikan, di dalam UUD 1945 sudah ditegaskan bahwa tanggung jawab dalam pelaksanaan HAM berada pada pemerintah ${ }^{3}$ Indonesia

${ }^{1}$ Manan, Bagir. (2001). Perkembangan Pemikiran dan Pengaturan Hak Asasi Manusia di Indonesia, Bandung: Alumni, h. 30-32

2 Soemantri, Sri. (2006). Prosedur dan Sistem Perubahan Konstitusi, Bandung: Alumni, h. 59-60

3 Affandi, Hernadi, Tanggung Jawab sebagai bagian dari masyarakat internasional harus menghormati, menghargai, dan menjunjung tinggi prinsip dan tujuanPiagam Perserikatan Bangsa-Bangsa serta Deklarasi Universal Hak-hakAsasi Manusia, yang selanjutnya disingkat DUHAM.

DUHAM ini berisipokok-pokok hak asasi manusia dan kebebasan dasar yang dijadikansebagai acuan dalam penegakan dan penghormatan hak asasi manusia baikbagi anggota PBB sendiri maupun masyarakat yang berada di wilayah yurisdiksinya, dalam perkembangannya, tanggal 16 Desember 1966, melalui resolusi 2200A (XXI)MU PBB mengesahkan Kovenan tentang Hak-hak Sipil dan Politik bersama-sama dengan Protokol Opsional pada Kovenan 28 tentang Hak-hak Sipil dan Politik dan Kovenan tentang Hak-hak Ekonomi, Sosial, dan Budaya. Kovenan Internasional tentang Hak-hak Sipil dan Politik beserta Protokol Opsional pada Kovenan Internasional tentang Hak-hak Sipil dan Politik mulai berlaku pada tanggal 23 Maret $1976{ }^{4} \mathrm{Hal}$ ini disertai konsekuensi bahwa Pemerintah Indonesia memiliki tanggungjawab untuk memenuhi pelaksanaan hak sipil dan politik setiap warganegara.

Hak-hak politik yang diatur dalam DUHAM diantaranya Berhak turut serta dalam pemerintahan negaranya secara langsung atau melalui wakil-wakil yang dipilih secara bebas; Berhak atas kesempatan yang sama untuk diangkat dalam jabatan pemerintahan negaranya; Kemauan rakyat harus menjadi dasar kekuasaan pemerintah, dimana kehendak ini harus dinyatakan dalam pemilihan umum yang dilaksanakan secara berkala dan murni, dengan hak pilih yang bersifat

Negara Dalam Melindunggi Hak atas Atas Pendidikan Dalam UUD 1945, Jurnal hukum Positum, h. 223

4 Penjelasan Undang-undang Nomor 12 Tahun 2005 tentang Pengesahan International Covenant On Civil And Political Rights (Kovenan Internasional Tentang Hak-Hak Sipil Dan Politik) 
umum dan setara, dengan pemungutan suara secara rahasia ataupun dengan prosedur lain yang menjamin kebebasan memberikan suara ${ }^{5}$ Salah satu hak politik yang dijamin dalam kovenan internasional sesperti ICCPR adalah hak setiap warga negara untuk ikut serta dalam penyelenggaraan urusan publik atau urusan politik seperti contoh untuk memilih dan dipilih, serta mempunyai akses berdasarkan persyaratan umum yang sama pada jabatan publik di negaranya, konstitusi Indonesia juga memuat ketentuan tentang hak pilihyang termuat dalam Pasal 28 yaitu hak setiap warga negara untuk memilih dan dipilih dalam rangka lembaga perwakilan rakyat, mewujudkan penyelenggaraan negara yang mendeklarasikan diri Indonesia menganut kedaulatan di tangan rakyat berdasarkan perwakilan rakyat, maka di Indonesia diselenggarakan pemilihan umum untuk memilih wakil rakyat di DPRD kabupaten /kota, DPRD Provinsi, DPR RI, DPD, Presiden dan Wakil Presiden secara berkala setiap lima (5) tahun sekali. Hal ini jugamerupakan suatu perwujudan pemenuhan hak sipil politik untuk memilih maupun dipilih dalam rangka lembaga perwakilan rakyat sebagai wakil suara rakyat. Pemilihan umum mempunyai kaitan erat dengan penyelenggaran negara demokrasi dan negara hukum.

Adanya pemilu merupakan salah satu pelaksanaan demokrasi dalam suatu negara. diantara ciri negara hukum yang berkaitan denganpemilu adalah perlindungan terhadap hak asasi manusia, persamaan didepan hukum dan pemerintahan serta adanya pemilihan umum yang bebas jujur adil hak asasi rakyat yang berkaitan dengan bidang politik dapat disalurkan, hak untuk sama depan hukum dan pemerintahanjuga mendapat saluran, dan dengan adanya pemilu yang bebas jujur adil tujuan pemilu sebagai sarana penyaluran hak demokratis atau hak politik rakyat Sejumlah masalah muncul menjelang pelaksanaan Pemilu dan Pilpres 2019. Mulai dari masalah logistik hingga daftar pemilih tetap (DPT), untuk masalah logistik, ditemukan di sejumlah daerah surat suara yang mengalami kerusakan. Kemudian, banyak lagi ditemukan surat suara rusak di sejumlah daerah lainnya. Di antaranya di Jakarta Barat, Kabupaten Agam, Kota Banjarmasin, Kota Surabaya, Kabupaten Agam, Kota Palangka Raya, dan lain sebagainya. Rata-rata kerusakan dalam bentuk sobek atau berlubang. Anggota Direktorat Advokasi dan Hukum Badan Pemenangan Nasional (BPN) Prabowo-Sandiaga, Ferdinand Hutahaean menilai banyaknya temuan kotak suara yang rusak dikhawatirkan menghambat proses pemilu. BPN khawatir banyak kotak suara tidak bisa digunakan pada pemilu 17 April 2019 mendatang."Ini akan menjadi masalah besar bagi demokrasi kita, inilah yang selalu kita khawatirkan dulu terhadap KPU mengapa mengadakan kotak suara dari kotak kardus yang sama sekali tidak mampu menjaga suara masyarakat," KPU seharusnya berpikir jernih, sejak awal ia juga menyayangkan keputusan KPU yang memakai kotak berbahan dasar kardus sebagai kotak suara. "Kalau pengamannya saja cuma kardus yang gampang rusak oleh air apalagi kena api? Ini kan akan mengancam barang bukti dari hasil suara rakyat yang dipungut pada saat hari pemilu 17 April nanti, berharap agar KPU bisa lebih mewaspadai agar hal-hal yang tidak diinginkan terjadi. Apalagi, imbuhnya, akhir-akhir ini bertepatan dengan musim hujan. KPU mengantisipasinya setidak-tidaknya menjaga gudang KPU menyimpan kotak suara dengan baik. Tim Kampanye Nasional (TKN) Joko Widodo-Ma'ruf Amin meminta penyelenggara pemilu untuk segera memperbaiki kerusakan yang terjadi terhadap kotak suara di sejumlah daerah. Perbaikan diperlukan

\footnotetext{
5 Pasal 21 DUHAM
} 
guna memastikan hak konstitusional warga, agar nilai demokrasi nasional tetap terjaga.

Hal ini, KPU Pusat akan melakukan pencetakang ulang atas surat suara yang rusak. Pencetakan ulang diperkirakan dilakukan pada satu hingga dua hari setelah laporan kerusakan diterima. Berdasarkan jadwal tersebut, menurut Arief Budiman bahwa distribusi hingga kecamatan bisa diselesaikan sebelum 5 April 2014, karena jarak ibu kota ke kecamatan tidak terlalu jauh. "Kalau daratan paling 2 jam. Kepulauan memang ada yang dibutuhkan tiga hari karena harus gunakan kapal laut dan jadwalnya tak reguler,"6

Dari beberapa ,masalah dalam pemilu serentak 2019 ini Persoalan lain dari format pemilu tersebut adalah fakta bahwa penyelenggaraan pemilu legislatif dan pemilu presiden di lakukan secara bersamaan artinya pemilu 2019 ini di lakukan serentak, sedangkan dalam pemilu presiden dan wakil presiden, sistem dilakukan dengan dua cara, yaitu. Pertama, pemilu secara langsung (populary elected) adalah calon yang mendapatkan suara terbanyak ditetapkan sebagai presiden terpilih, Sedangkan dalam pemilu tidak langsung (electoral college) adalah dilakukan melalui porsi suara wakil rakyat (DPRD Provinsi atau DPRD Kabupaten/ Kota), dalam penggunaan desain pemilu serentak pada pemilu 2019, praktek yang banyak digunakan adalah penggabungan antara pemilihan eksekutif dengan pemilihan legislatif. Secara bersamaan Desain ini banyak digunakan di negara-negara Amerika Latin. Pemilu serentak di Indonesia di kategorikan salah satu terumit di dunia di karenakan system nya yang masih di lakukan secara konvensional.

${ }^{6} \mathrm{https}$ ://nasional.republika.co.id sejumlah masalah yang muncul menjelang pemilu dan pilpres. (Diakses pada Tanggal 15 April 2019).

\section{B. PEMBAHASAN}

\section{Perlindungan Hak Pilih dalam UUD 1945}

Perlindungan Hak Asasi Manusia dan Warga Negara. Hak Asasi Manusia dalam menyebutkan bahwa Hak Asasi Manusia adalah seperangkat hak yang melekat pada hakikat dan keberadaan manusia sebagai makhuk Tuhan Yang Maha Esa dan merupakan anugerah-Nya yang wajib dihormati, dijunjung tinggi dan diindungi oleh negara, hukum dan Pemerintah, dan setiap orang demi kehormatan serta perlindungan harkat dan martabat manusia. Sebagaimana kita ketahui, di samping hak asasi tentu ada kewajiban asasi, yang dalam hidup bermasyarakat semestinya pemenuhan kewajiban itu terlebih dahulu dilaksanakan. Menurut sejarah dikatakan bahwa asal mula

Hak Asasi Manusia ialah dari Eropa Barat yaitu Inggris.Pada tahun 1215, lahir Magna Charta yang isinya menjelaskan bahwa raja tidak lagi bertindak sewenangwenang. Perkembangan selanjutnya ialah Revolusi Amerika 1776 yang menuntut adanya hak bagi setiap orang untuk hidup merdeka, dalam hal ini hidup bebas dari kekuasaan Inggris. Kemudian Revousi Perancis 1789 yang bertujuan membebaskan manusia warga negara Perancis dari kekangan kekuasaan mutlak seorang raja penguasa tunggal negara yang pada saat itu adalah Raja Louis XVI. Istilah yang dipakai saat itu untuk Hak Asasi Manusia adalah"droit de l'homme" yang berarti "hak rechten" (bahasa Belanda), dalam bahasa Indonesia biasa disalin dengan "hak-hak kemanusiaan"" .Macam-macam Hak Asasi Manusia yang patut dihormati dapat dibedakan sebagai berikut :Hak asasi atas pribadi "personal rights" yang meliputi kebebasan menyatakan pendapat,

7 http://ditjenpp.kemenkumham.go.idjudul hak politik suatu negara sebuah perbandingan konstitusi, (Diakses pada Tanggal 29 April 2019). 
kebebasan memeluk agama, kebebasan bergerak dan sebagainya Hak asasi ekonomi atau "property rights" yaitu hak untuk memiliki sesuatu, membei dan menjualnya serta memanfaatkannya. Hak asasi manusia untuk mendapatkan perlakuan yang sama dalam hukum dan pemerintahan atau biasa yang disebut "rights of legal equaity" Hak asasi politik atau "political rights", yaitu hak untuk ikut serta dalam pemerintahan, hak pilih (memilih dan dipilih dalam pemilihan umum), hak mendirikan partai politik dan sebagainya. Hak asasi sosial dan kebudayaan atau "social and culture rights", misalnya hak untuk memiih pendidikan, mengembangkan kebudayaan dan sebagainya Hak asasi Untuk mendapatkan perlakuan tata cara peradilan dan perlindungan atau "procedural rights", Misalnya peraturan dalam hal penangkapan, penggeledahan, peradilan dan sebagainya. Menjadi Kewajiban Pemerintah atau Negara Hukum untuk mengatur pelaksanaan hak asasi ini, yang berarti menjamin pelaksanaannya, mengatur pembatasanpembatasan demi kepentingan umum, kepentingan bangsa dan negara ${ }^{8}$.

Ada 2 (dua) hal ketentuan yang berkaitan dengan hak asasi dalam UUD yang disahkan tanggal 18 Agustus 1945. Pertama, hak asasi yang secara eksplisit dimuat sebagai kaidah kontitusi (individual), yaitu Pasal 27 (persamaan di depan hukum, hak atas pekerjaan dan penghidupan yang layak), Pasal 29 (kebebasan beragama dan menjalankan ibadah menurut agama dan kepercayaan), serta Pasal 31 (hak memperoleh pengajaran). Bahkan UUD telah menentukan hak-hak asasi ekonomi dan social sebagaimana diatur dalam Pasal 33 dan Pasal 34 UUD 1945. Kedua UUD memerintahkan "hak atas kemerdekaan

${ }^{8}$ Ibid http://ditjenpp.kemenkumham.go.id http://ditjenpp.kemenkumham.go.id judul hak politik suatu negara sebuah perbandingan konstitusi, (Diakses pada Tanggal 29 April 2019) berserikat dan berkumpul, mengeluarkan pikiran ... dan lain-lain" diatur dengan undang-undang (Pasal 28) Jaminan Pasal 28 termasuk jaminan yang 'implied' karena itu serta merta diterima oleh erhadap pasal penunjuk ini.Pertama, pendapat yang mengatakan bahwa karena masih akan atau harus diatur dengan undangundang,organik.

Ada 2 (dua) pandangan terhadap pasal penunjuk ini. Pertama, pendapat yang mengatakan bahwa karena masih akan atau harus diatur dengan undangundang, ${ }^{9}$ dalam Undang-Undang Dasar 1945 Amandmen ke-4, Pasal 22E sudah ditetapkan bahwa pemilu di Indonesia harus berupa pemilu yang umum, bebas, rahasia, jujur, dan adil (luber-jurdil) yang dilakukan setiap lima tahun sekali. Sementara itu, Pasal 43 Ayat (1) UU No 39 Tahun 1999 tentang Hak Asasi Manusia juga menegaskan hal yang sama, dengan menyebutkan, "Setiap warga negara berhak untuk dipilih dan memilih berdasarkan persamaan hak melalui pemungutan suara yang langsung, umum, bebas, rahasia, jujur, dan adil sesuai dengan ketentuan perundang-undangan," dalam standar internasional penegakan HAM, maka pelaksanaan pemilu merupakan sarana untuk mewujudkan: (a) hak untuk berperan dalam pemerintahan (right to take part in government); (b) hak untuk memilih dan dipilih (right to vote and to be elected); dan (c) hak untuk memperoleh kesetaraan akses dalam pelayanan publik (right to equal access to public service).

Di Indonesia, hak asasi warga Negara untuk turut serta dalam pemerintahan diatur secara khusus dalam Undang-Undang Dasar 1945 Amandmen ke-4, Pasal 28D Ayat (3) yang menyatakan,"Setiap warga negara berhak memperoleh kesempatan yang sama

9 Manan, Bagir, Susi Dwi Harijanti. (2016). “Konstitusi Dan Hak Asasi Manusia” Jurnal Ilmu Hukum Universitas Padjajaran Volume 3 Nomor 3, h. 455 
dalam pemerintahan." Ketentuan mengenai hak untuk turut serta dalam pemerintahan juga diatur dalam Pasal43 dan 44 UU Nomor 39 Tahun 1999 tentang HAM ${ }^{10}$ Sementara dalam Kovenan Internasional Hak-Hak Sipil dan Politik (International Covenant on Civil and Political Rights/ICCPR 1966),5. Pasal 25 menyatakan,"Setiapwarga negara mempunyai hak dan kesempatan, tanpa pembedaan sebagaimana dimaksud dalam Pasal 2 dan tanpa pembatasan yang tidak wajar, untuk: (a) ikut serta dalam penyelenggaraan pemerintahan, baik secara langsung ataupun melalui perwakilan yang dipilih secara bebas; (b) memilih dan dipilih pada pemilihan umum berkala yang jujur, dengan hak pilih yang universal dan sederajat, dan dilakukan dengan pemungutan suara yang rahasia yang menjamin kebebasan para pemilih menyatakan keinginannya; dan (c) mendapatkan akses, berdasarkan persyaratan yang sama secara umum, pada dinas pemerintahan di negaranyaPrinsip HAM universal menyebutkan negara wajib menjamin hak memilih (right tovote) dan hak untuk dipilih(right to beelected), karena setiap negara diminta untuk menerbitkan peraturan perundangundangan dan upaya lain yang diperlukan untuk memastikan setiap warga negara tanpa diskriminasi berdasarkan apa pun memperoleh kesempatan yang efektif menikmati hak ini supaya tercapailah kepastian hukum, keadilan dan kemanfaatan.

\section{Kewajiban negara dalam melindungi hak pilih}

Munculnya keinginan untuk melakukan pembatasan yuridis terhadap kekuasaan, pada dasarnya, dikarenakan politik kekuasaan yang cenderung korup. Hal ini dikhawatirkan akan menjauhkan

\footnotetext{
${ }^{10}$ Pasal 43 Ayat (2) UU Nomor 39 Tahun 1999, "Setiap warga negara berhak berhak turut serta dalam pemerintahan dengan langsung atau dengan perantaraan wakilyang dipilihnya,dengan
}

fungsi dan peran negara bagi kehidupan individu dan masyarakat. Atas dasar itu, terdapat keinginan yang besar agar dilakukan pembatasan kekuasaan secara yuridis-normatif untuk menghindari penguasa yang otoriter. Di sinilah konstitusi menjadi penting artinya bagi kehidupan masyarakat. Konstitusi dijadikan sebagai perwujudan hukum tertinggi yang harus dipatuhi oleh negara dan pejabat-pejabat pemerintah, sesuai dengan dalil government by laws, not by men (pemerintahan berdasarkan hukum bukan berdasarkan manusia ${ }^{11}$

Kewajiban negara dalam Penghormatan Terhadap Hak Asasi Manusia dapat dibedakan menjadi dua yaitu Kewajiban Langsung (Immediate Obligations) dan Kewajiban Progresif (Progresive Obligations). Kewajiban Langsung negara terhadap Hak Asasi Manusia seringkali diwujudkan dalam bentuk proses yuridis, sementara Kewajiban Progresif adalah kewajiban yang bisa ditanggalkan apabila kekurangan sumber daya penunjang. Kewajiban Negara untuk Menghormati (Penghormatan) Hak Asasi Manusia dan Kewajiban Untuk Melindungi (Perlindungan) Hak Asasi Manusia dilihat sebagai Kewajiban Langsung. Terdapat juga kewajiban secara hukum yang terkait langsung dengan Pemenuhan Terhadap hak Asasi Manusia. Generasi pertama, perkembangan hak-hak sipil dan politik (seperti: hak untuk hidup, kebebasan dan keamanan pribadi, persamaan hak di depan hukum, hak atas nama baik, hak untuk bebas dari pembatasan bergerak dan berdomisili, hak untuk bebas berpikir, berkeyakinan, dan beragama, kebebasan berbicara, hak atas informasi, hak untuk memilih dan dipilih, hak untuk referendum, dsb) Setidaknya terdapat beberapa ketentuan dalam UUD 1945 yang dapat dijadikan landasan

bebas

${ }^{11}$ Budihardjo, Miriam. (1983). Dasar-Dasar Ilmu Politik, Jakarta: Gramedia, h. 57 
konstitusional guna menjamin hak politik contohnya pasal 22 UUD, Pasal 27,28 yang mengatur hak warga negara untuk memilih (right to vote). Sejumlah ketentuan dimaksud di antaranya, Pasal 27 ayat (1) UUD 1945 disebutkan bahwa segala warga negara bersamaan kedudukannya di dalam hukum dan pemerintahan dan wajib menjunjung hukum dan pemerintahan dengan tidak ada kecualinya. Kemudian terdapat pula Pasal 28D ayat (1) bahwa: "setiap orang berhak atas pengakuan, jaminan, perlindungan dan kepastian hukum yang adil serta perlakuan yang sama di hadapan hokum".

Tentu yang tidak kalah pentingnya adalah ketentuan Pasal 28 D ayat (3) yang berbunyi bahwa setiap warga negara berhak memperoleh kesempatan yang sama dalam pemerintahan. Beberapa ketentuan dalam konstitusi tersebut cukup menunjukkan bagaimana sesungguhnya perlindungan negara terhadap warga negaranya dan negara menjamin dan melindungi hak konstitusional warga negara, khususnya terkait dengan hak politik dalam memberikan hak pilihnya di setiap pelaksanaan demokrasi langsung.Hanya saja dalam pelaksanaannya lebih lanjut bahwa seluruh ketentuan dalam konstitusi tidak selalu dimaknai secara komprehensif olehpara pembuat regulasi di tingkatan yang lebih rendah. UU No. 7 Tahun 2017 adalah UU yang mengatur tentang pemulihan umum perlindungan di dalam UU ini dalm peraktiknya masih banyak yang sulit di lakukan karena masalah seperti data kependudukan dan admistrasi kependudukan di Indonesia masih bermasalah Padahal UU itu merupakan UU yang termasuk bentuk pengaturan lebih lanjut penyelenggaraan pemilihan umum sebagaimana diamanatkan UUD 1945

Seperti di Indonesia yang diatur dalam pasal 33 Undang-Undang dasar 1945 Kewajiban negara tidak terbatas pada kedua kewajiban tersebut, karena
Hukum Internasional dan masyarakat Internasional melihat wajib bagi negara untuk menerapkan konsep Due Diligence dalam Perlindungan hak asasi manusia. Negara diwajibkan untuk memenuhi standar tertentu berdasarkan akal dan kebiasaan dalam usahanya memenuhi kewajiban terkait Hukum Dasar perlindungan hukum atas HAM di Indonesia terdapat dalam Pembukaan Undang-Undang Dasar 1945 alinea IV, Bab XA Undang-Undang Dasar 1945 (Pasal 28A sampai dengan Pasal 28J), Undang-Undang Nomor 39 Tahun 1999 tentang Hak Asasi Manusia, serta Undang-Undang Nomor 26 Tahun 2000 tentang Pengadilan HAM3 Pasal 28 I ayat (4) UUD 1945 secara tegas menyatakan bahwa perlindungan, pemajuan, penegakan, dan pemenuhan hak asasi manusia adalah tanggung jawab negara, terutama pemerintah sebagai penjamin perlindung hak asasi Manusia

Demikian pula dijelaskan dalam Undang-Undang Nomor 39 Tahun 1999 tentang HAM Pasal 71 yang menyatakan: "Pemerintah wajib dan bertanggung jawab menghormati, melindungi, menegakkan, dan memajukan hak asasi manusia yang diatur dalam undangundang ini, peraturan perundang-undangan lain, dan hukum internasional tentang hak asasi manusia yang diterima oleh negara Republik Indonesia".

Berdasarkan perintah undangundang tersebut telah jelas bahwa pemerintah mempunyai tanggung jawab untuk menghormati, melindungi, menegakkan, dan memajukan hak asasi manusia. Secara universal bahwa negara memikul tanggung jawab utama dalam pemajuan dan perlindungan hak asasi manusia. Tanggung jawab yang sedemikian tak dapat dikurangi dengan alasan-alasan politik, ekonomi maupun budaya. Sementara itu dalam kenyataan sehari-hari banyak pelanggaran hak asasi manusia dilakukan oleh negara melalui organ-organ atau Aparatnya baik sipil maupun militer yang menyelewengkan 
kekuasaannya (abuse of power). ${ }^{12}$ HAM merupakan kodrat yang melekat dalam diri setiap manusia sejak ia dilahirkan kedunia. Secara kodrati antara lain manusia mempunyai hak kebebasan. Negara demokrasi merupakan alat dari masyarakat yang diberi wewenang oleh masyarakat untuk menjalankan suatu kekuasaan, yang bertujuan untuk melindungi hak-hak warga Negara dan Negara kesejahteraan (Welfare state) menjadikan hak-hak warga Negara sebagai dasar membuat kebijakan. Negara kesejahteraan yang demokratis memiliki tugas dan tanggungjawab sebagai berikut:

a) Menegakkan hak atas kemerdekaan dan persamaan bagi setiap warga Negara di hadapan hukum;

b) Membuat dan melaksanakan aturanaturan hukum nasional yang adil dan tidak diskriminasi terhadap warga Negara;

c) c.Membela, melindungi warga Negara dari berbagai bentuk ancaman dan bahaya;

d) Memajukan kesejahtraan sosial warganya;

e) Mencerdaskan kehidupan bangsa;

f) Ikut serta dalam segala upaya pemeliharaan ketertiban dunia yang berdasarkan pada perdamaian abadi dan keadilan sosial.

Pada intinya Negara yang bertanggung jawab adalah Negara yang menghargai dan menegakkan hak-hak yang dimiliki oleh warga Negaranya, melindungi warganya dari berbagai ancaman bahaya, mempublikasikan hakhak yang dimiliki oleh warga Negaranya secara transparan, dan senantiasa mengusahakan kesejahteraan hidup warganya. Hak-hak yang dimiliki oleh warga Negara merupakan kewajiban bagi sebuah Negara untuk melindunginya Rosevelt mengemukakan, bahwa dalam

${ }^{12}$ Bahagijo, Sugeng dan Asmara Nababan. (1999). Hak Asasi Manusi: Tanggung Jawab Negara Peran Institusi Nasional dan Masyarakat, Jakarta: KOMNAS HAM, h. viii. hidup bermasyarakat dan bernegara manusia memiliki empat kebebasan (The Four Freedoms), yaitu: a). kebebasan untuk berbicara dan menyatakan pendapat (Freedom of Speech); b). kebebasan beragama (Freedom of Religie), c). kebebasan dari rasa takut ( Freedom from Fear), d). kebebasan dari kemelaratan ( Freedom from Want $)^{13}$

Deklarasi PBB secara singkat menjelaskan seperangkat hak-hak dasar manusia yang sangat sarat dengan hak-hak yuridis, seperti hak untuk hidup, hak tidak menjadi budak, hak tidak disiksa dan ditahan, hak dipersamakan dimuka hukum, hak untuk mendapatkan praduga tak bersalah, dan sebagainya. Hak lain juga dimuat dalam deklarasi tersebut, seperti hak akan nasionalitas, pemilikan, dan pemikiran; hak untuk menganut agama dan memperoleh pendidikan, pekerjaan, dan kehidupan berbudaya ${ }^{14}$ Kovenan Hak-Hak Sipil dan Politik (ICCPR) memberikan tanggung jawab kepada negara pihak untuk untuk melakukan segala upaya perlindungan baik jaminan hukum atau kebijakan yang sesuai dengan Kovenan. Selain itu, Kovenan juga mewajibkan negara untuk melakukan tindakan pemulihan (remedy) bagi para korban pelanggaran hak-hak yang diatur dalam Kovenan. Pasal 2 ayat (3) Kovenan menyatakan bahwa negara pihak harus menjamin bahwa setiap orang yang hakhak atau kebebasannya diakui dalam Kovenan ini dilanggar, akan memperoleh upaya pemulihan yang efektif, walaupun pelanggaran tersebut dilakukan oleh orang-orang yang bertindak dalam kapasitas resmi, dan menjamin, bahwa setiap orang yang menuntut upaya pemulihan tersebut harus ditentukan hakhaknya itu oleh lembaga peradilan, administratif, atau legislatif yang berwenang, atau oleh lembaga berwenang lainnya yang diatur oleh sistem hukum

13 Eko Hidayat "Perlindungan HAM dalam Negara Hukum Indonesia" Jurnal Raden Intan Lampung, h. 81

${ }^{14}$ Ibid, h. 84 
Negara tersebut, dan untuk mengembangkan segala kemungkinan upaya penyelesaian peradilan.

UUD 1945 secara jelas menyebut bahwa perlindungan, pemajuan, penegakan dan pemenuhan HAM adalah tanggung jawab negara, utamanya pemerintah (Pasal 28I ayat 4), dalam UU No. 39 Tahun 1999 juga menyebut hal yang sama yakni Pemerintah mempunyai kewajiban dan bertanggung jawab untuk menghormati, melindungi, menegakkan dan memajukan HAM yang diatur dalam berbagai UU dan hukum internasional tentang HAM yang diterima oleh negara Republik Indonesia. UU No. 39 tahun 1999 memberikan jaminan bahwa setiap orang berhak untuk menggunakan semua upaya hukum nasional dan forum internasional atas semua pelanggaran hak asasi manusia yang dijamin oleh hukum Indonesia dan hukum internasional mengenai hak asasi manusia yang telah diterima negara Republik Indonesia, dengan kewajiban yang demikian, Negara, utamanya Pemerintah, bertanggungjawab dan memastikan adanya perlindungan, pemajuan, penegakan dan pemenuhan HAM. Upaya tersebut misalnya memastikan bahwa lembaga-lembaga negara dalam melaksanakan kewajibannya, mengambil atau membuat kebijakan harus berdasarkan nilai-nilai HAM, melakukan tindakan-tindakan untuk pemenuhan HAM, dan juga membentuk lembaga-lembaga khusus untuk memastikan penegakan HAM, misalnya Komnas HAM, Komnas Perempuan, Komnas Perlindungan Anak Indonesia, dll. Pemerintah daerah juga mempunyai fungsi ${ }^{15}$

Sebuah catatan yang perlu diingat tentang adanya kewajiban dan kebolehan bagi negara menandatangan (negara pihak) ICCPR. Kewajiban Negara pihak dalam Pasal 2 ayat (1) ICCPR ditentukan bahwa "Setiap negara pihak berusaha

\footnotetext{
${ }^{15}$ Abiding, Zainal Jurnal Perlindungan ham di Indonesia Elsam Indinesia, h. 13

16 Kasim, Ifdhal. (2001). Hak Sipil dan
}

menghormati dan menjamin semua hak individu yang berada di wilayahnya dan tunduk kepada yurisdiksinya yang diakui dalam Kovenan tanpa perbedaan apau pun, seperti ras, warna kulit, jenis kelamin, bahasa, agama, pendapat politik atau pendapat lain, asal usul kebangsaan atau latar belakang sosial, kekayaan, kelahiran atau status lain". ICCPR memperbolehkan negara-negara pihak ICCPR untuk mengurangi kewajiban dalam pemenuhan hak-hak tersebut. Walaupun keleluasan tersebut rawan disalahgunakan oleh negara, tetapi penyimpangan itu dimungkinkan apabila sebanding dengan ancaman yang dihadapi dan tidak bersifat diskriminatif, yaitu: a) menjaga keamanan/ moralitas umum, dan b) menghormati hak/ kebebasan orang lain ${ }^{16}$ Menurut UUD 1945 telah mendapatkan jaminan secara jelas dalam Pasal 27 ayat (1) dan Pasal 28 D ayat (3) dan secara tersirat dalam Pasal 1 ayat (2). Hak asasi ini lahir dari paham kedaulatan rakyat yakni pemerintahan dengan ciri kedaulatan di tangan rakyat ${ }^{17}$.

Pemerintahan harus membuka kesempatan kepada rakyat untuk turut serta menyelenggarakan pemerintahan rakyat, yang diistilahkan sebagai demokrasi yaitu pemerintahan negara yang berasal dari, oleh dan untuk rakyat, termasuk Hak pilih bagi warga negara, hak mencalonkan dan hak untuk dicalonkan, hak untuk memilih maupun hak untuk dipilih dalam penyelenggaraan Pemilihan Umum, merupakan salah hakyang sangat fundamental dalam kehidupan negara dan demokrasi dan sekaligus sebagai bukti adanya kedaulatan yang dimiliki rakyat dan eksistensinya dalam pemerintahan suatu Negara.

\section{Perlindungan Hak Pilih Dalam Pemilu 2019}

Deklarasi Universal HAM

Politik: Esai-Esai Pilihan . ELSAM, h. 17.

17 Pasal 27 UUD 1945 
khususnya Pasal 21 ayat (3). Hal ini biasanya dengan merujuk kutipan dari naskah tersebut, bahwa: "Kehendak rakyat harus menjadi dasar kekuasaan pemerintah; kehendak ini harus dinyatakan dalam pemilihan umum yang dilaksanakan secara berkala dan murni, dengan hak pilih yang bersifat umum dan sederajat, dengan pemungutan suara secara rahasia ataupun dengan prosedur lain yang menjamin kebebasan memberikan suara," dengan pengaturan itu, maka pemerintah diposisikan sebagai pelaksana kewajiban, yakni kewajiban untuk melindungi pelaksanaan hak politik warga negaranya dan menyelenggarakan pemilihan umum untuk memilih orangorang yang duduk dalam pemerintahan.

Bagaimana sebuah lembaga internasional dapat memunculkan kewajiban negara kita, dalam bagaimana warga negaranya bisa memastikan dirinya terjaring dalam skema pencatatan identitas dirinya Memang, dalam keperluan ini, lembaga legislatif seperti DPR RI telah menyediakan pengaturan berupa undangundang dan pengaturan lainnya yang memungkinkan terlaksananya penjaminan hak warga negara baik dalam pencatatan identitasnya maupun dalam pelaksanaan pemilunya.Namun ternyata ketersediaan undang-undang maupun institusi penyelenggara saja tidak cukup untuk menjelaskan bagaimana proses pewajiban negara terhadap dirinya dirinya sendiri. Telaah akan hal itu, kiranya akan membantu menelaah bagaimana seluruh warga negara dapat mempermasalahkannya termasuk Penyelenggara Pemilu (dalam hal ini adalah Komisi Pemilihan Umum/KPU) bila dalam penyelenggaraan pemilu, hak pilih warga negara diabaikan. Sementara itu, penjaminan hak yang jelasjelas diminati adalah penjaminan hak untuk dipilih. Acuannya juga bersifat normative, bahwa, dalam setiap penyelenggaraan pemilu, setiap warga negara bisa memilih mzupun di pilih dan negara wajib melundunginya selain itu kebijakan procedural hak asasi tidak boleh membatasi hak subtantif seseorang Pasal 22 E UUD 1945 selalu disebutsebut. Di sana dikatakan bahwa: "anggota Dewan Perwakilan Rakyat (DPR) dipilih melalui pemilihan umum ${ }^{18}$ ".

Dari ketentuan ini, konstitusi tegas mengatakan warga negara bisa masuk ke dalam domain negara. Untuk itu, harus diselenggarakan pemilu. Agar pemilu betul-betul memiliki legitimasi kuat, selalu diingatkan amanat konstitusi untuk menyelenggarakan pemilu dengan kualifikasi ketat. Pemilu harus dilaksanakan secara langsung, umum, bebas, rahasia, jujur, dan adil.

Perubahan terhadap UUD 1945 telah mengatur bahwa Hak memberikan suara atau memilih (right to vote) telah diakui sebagai hak dasar (basic right) yang dimiliki oleh setiap manusia, terlebih sebagai warga negara yang dijamin secara konstitusional oleh Negara. Ketentuan tentang hak untuk memilih dan dipilih (termasuk di dalamnya hak untuk mencalonkan dan dicalonkan) memuat prinsip kesetaraan bagi seluruh warga negara, sehingga tidak dibenarkan adanya diskirminasi karena perbedaan suku, bahasa, budaya, agama dan keturunan. Ketentuan UUD 1945 mewajibkan negara untuk memenuhi segala bentuk hak asasi setiap warga negaranya dalam Pemilihan Umum (Pemilu) secara langsung sebagai hak pilih aktif (memlih) dan hak pilih pasif (dipilih), yakni Pemilihan anggota legislatif (Pileg) DPR dan DPD, Pemilihan Presiden (Pilpres) dan Pemilihan Kepala Daerah (Pilkada) di Indonesia, maupun pemilihan secara tidak langsung dengan cara diwakili oleh para wakil rakyat (DPR dan Presiden) dalam UUD 1945 pasca perubahan (hak pilih pasif) untuk memilih hakim MK (Pasal 24 C ayat 3), hakim MA (Pasal 24 B ayat 1)

${ }^{18}$ Pasal 22 E UUD 1945 
dan Komisi Yudisial (KY) (Pasal 24 B ayat 3). Dan berbagai Pasal tersebut sangat terkait dengan hak untuk memiliih dan dipilih dalam Pasal 27 ayat (1) Pasal 28, Pasal 28D ayat (3), Pasal 28E ayat (3) UUD 1945 pasca perubahan.

Ketentuan lebih lanjut UUD 1945 pasca perubahan dalam Pasal 2 ayat (1) tentang anggota MPR terdiri dari anggota DPR dan DPD yang dipilih melalui pemilihan umum, Pasal 6A (1) tentang pemilihan presiden, Pasal 18 ayat (3) tentang pemilihan kepala daerah, Pasal 18 ayat (4) tentang pemilihan anggota DPRD, Pasal 19 ayat (1) tentang pemilihan anggota DPR dan Pasal 22C (1) tentang pemilihan anggota DPD, diatur dalam UU MD3, UU Pemerintahan Daerah, UU Pemilihan Umum. Sedangkan ketentuan lebih lanjut tentang pemilihan hakim $\mathrm{MK}$ (Pasal $24 \mathrm{C}$ ayat 3), hakim MA (Pasal 24 B ayat 1) dan Komisi Yudisial (KY) (Pasal $24 \mathrm{~B}$ ayat 3 ), diatur lebih lanjut dalam UU MK, UU MK dan UU KY. Sedangkan dalam Undang-Undang Nomor 39 Tahun 1999 Tentang Hak Asasi Manusia diatur dalam Pasal 23 ayat (1) dan Pasal 43 ayat (1) yang menjadi dasar hukum bagi setiap warga negara Indonesia untuk memiliki kebebasan untuk ikut serta menentukan wakil-wakil mereka, baik untuk duduk dalam lembaga legislatif maupun dijadikan sebagai pimpinan lembaga eksekutif yang dilakukan melalui Pemilihan Umum. Hak pilih (secara langsung atau tidak langsung, hak pilih aktif atau hak pilih pasif)) yang diatur dalam berbagai peundang-undangan di Indonesia merupakan hak asasi manusia yang dapat diimplementasikan sebagai hak warga negara dalam Pemilihan yang demokratis. Oleh karena itu pemilihan ummum yang diikiuti setiap warga negara harus dilaksanakan dengan jaminan langsung, umum, bebas, rahasia, jujur dan adil, tanpa ada diskriminasi, intervensi maupun intimidasi. ${ }^{19}$

Jargon ini selalu disosialisasikan

19 Jatmiko, Bayu D. "Hukum Menelisik Pengakuan Hak Politik Pasca Perubahan UUD oleh KPU sebagai penyelangarra pemilu di Indonesia demi legitimasi mereka yang nantinya terpilih dalam hal ini, diperlakukannya DPT sekedar sebagai persoalan administrative melainkan persoaln hak dan kewajiban suaitu negara dalam melindunginya, adalah kesalahan yang di satu sisi sangat latent namun, di sisi lain juga fatal karena DPT menjadi kunci perlindungan hak pilih warga persoalan 'kisruh DPT pemilu', kisruh DPT ini pangkal persoalnya sebenarnya burukya system data kependudukan khususnya terkait dengan data base kependudukan yang selelu setiaptahun diperbaiki.

\section{PENUTUP}

Persoalan perlindungan hak pilih ini mesti menjadi perhatian khusus karena UUD 1945 pasal 22,27,28 telah sangat jelas bagaimana perlindungan hak pilih maupun hak untuk meilih KPU sebagai yang menjadi penagung jawab terhadap perlindungan hak pilih warga negara maupun hak di pilih agar selalu melindungi hak pilih mapun hak di pilih warga negaranya dengan cara aktif mesosialisasikan persoalan hak pilih ini kepada public dalam kaitan persoalan admistrative seringkali mejadi masalah yang selalu ada menjelang perhelatan pemilihan umum hal ini menimbulkan sesuatu masalah kelasik yang terus di coba untuk di selesaikan namun hal ini tetap saja belum tuntas persoalan hak pilih ini sangat penting kaitan nya dengan hak dan kewajiban masyarakat maupun negara

\section{DAFTAR PUSTAKA}

Budihardjo, Miriam. (1983). Dasar-Dasar Ilmu Politik, Jakarta: Gramedia. Bahagijo, Sugeng dan Asmara Nababan.

1945”. Jurnal Panorama Hukum, h. 241-242 
(1999). Hak Asasi Manusi: Tanggung Jawab Negara Peran Institusi Nasional dan Masyarakat, Jakarta: KOMNAS HAM.

Manan, Bagir. (2001). Perkembangan Pemikiran dan Pengaturan Hak Asasi Manusia di Indonesia, Bandung: Alumni.

Soemantri, Sri. (2006). Prosedur dan Sistem Perubahan Konstitusi, Bandung: Alumni.

\section{Lain-Lain}

Affandi, Hernadi tanggung jawab negara dalam melindunggi Ha katas Atas Pendidikan Dalam UUD 1945. Jurnal hukum Positum.

Hidayat, Eko. Perlindungan HAM dalam Negara Hukum Indonesia, Jurnal Raden Intan Lampung.

Jatmiko, Bayu D Menelisik Pengakuan Hak Politik Pasca Perubahan UUD 1945, Jurnal Panorama Hukum.

Manan, Bagir dan Susi Dwi Harijanti. (2016). Konstitusi Dan Hak Asasi Manusia Jurnal Ilmu Hukum Universitas Padjajaran Volume 3 Nomor 3.

https://nasional.republika.co.id sejumlah masalah yang muncul menjelang pemilu dan pilpres

http://ditjenpp.kemenkumham.go.idjudul hak politik suatu negara sebuah perbandingan konstitusi 